Article

\title{
Antimicrobial Efficiency of Metallurgical Slags for Application in Building Materials and Products
}

\author{
Július Strigáč ${ }^{1, *}$, Nadežda Števulová ${ }^{2}$ (D) , Jozef Mikušinec ${ }^{1}$, Ludovít Varečka ${ }^{3}$ and \\ Daniela Hudecová 3 \\ 1 Povazska Cement Plant Ladce, 01863 Ladce, Slovakia; mikusinec.j@pcla.sk \\ 2 Institute of Environmental Engineering, Faculty of Civil Engineering, Technical University of Košice, \\ 04200 Košice, Slovakia; nadezda.stevulova@tuke.sk \\ 3 Institute of Biochemistry and Microbiology, Faculty of Chemical and Food Technology, Slovak University of \\ Technology in Bratislava, 81237 Bratislava, Slovakia; daniela.hudecova@stuba.sk (L.V.); \\ ludovit.varecka@stuba.sk (D.H.) \\ * Correspondence: strigac.j@pcla.sk; Tel.: +421-42-4603-463
}

Received: 21 November 2017; Accepted: 9 February 2018; Published: 17 February 2018

\begin{abstract}
The article deals with studying the antimicrobial efficiency of finely ground metallurgical slags, such as granulated blast-furnace slag with specific surface areas of 340 (1Sa) and $520 \mathrm{~m}^{2} / \mathrm{kg}$ (1Sb), air cooled blast-furnace slag (2S), demetallized steel slag (3S), calcareous ladle slag (4S), and copper slag (5S). The efficiency was tested on microbial representatives, such as: Gram-positive bacteria-Bacillus subtilis, Staphylococcus aureus, Micrococcus luteus; Gram-negative bacteria-Escherichia coli, Pseudomonas aeruginosa, Serratia marcescens; yeasts-Candida utilis, Rhodotorula glutinis; and microscopic filamentous fungi-Aspergillus niger, Penicillium funiculosum, Chaetomium globosum, Alternaria alternata, Trichoderma viride, Cladosporium herbarum. The efficiency was determined by dilution methods in agar growth media so that the resulting concentration of the tested slags was 10,20,40, and $60 \%$. The antibacterial efficiency of the slags decreased in the order: $\mathrm{S} 4>\mathrm{S} 3>\mathrm{S} 2>\mathrm{S} 1 \mathrm{a}=\mathrm{S} 1 \mathrm{~b}>\mathrm{S} 5$, while their anti-yeast efficiency decreased in the order S4 $>\mathrm{S} 1 \mathrm{a}$ $=\mathrm{S} 1 \mathrm{~b}=\mathrm{S} 3>\mathrm{S} 2>\mathrm{S} 5$. Microscopic filamentous fungi were selectively sensitive to the slags; therefore, there is only an approximate order of efficiency of $\mathrm{S} 4>\mathrm{S} 3=\mathrm{S} 1 \mathrm{a}=\mathrm{S} 1 \mathrm{~b}>\mathrm{S} 5>\mathrm{S} 2$. Application of metallurgical slags into building materials and products provide them with increasing resistance against biodeterioration.
\end{abstract}

Keywords: metallurgical slags; antimicrobial efficiency; bacteria; yeasts; microscopic filamentous fungi; biodeterioration resistance

\section{Introduction}

Biocorrosion of concretes, mortars, and building materials and products is a serious problem wherever the conditions suitable for particular microorganisms occur. Biodeterioration reduces the utility efficiency of concretes, as well as their service life. Biocorrosion, as a specific type of chemical corrosion, is caused by various biogenic organic acids and mineral acids (sulphuric acid, $\mathrm{H}_{2} \mathrm{SO}_{4}$, and nitric acid, $\mathrm{HNO}_{3}$ ), as well as by corrosive hydrogen sulphide, $\mathrm{H}_{2} \mathrm{~S}$, and ammonia, $\mathrm{NH}_{3}$, which result from the metabolic activity of microorganisms [1-4]. These aggressive metabolites react mainly with calcareous components of concrete and mortar stone, with development of their non-binding calcareous salts. Some of them cause sulphate degradation, resulting in extreme expansion in the hardened concrete and leading to the complete destruction of concrete structural elements.

The effects of different concrete compositions and exogenously added nutrients on fungal colonization and fouling was studied in [5]. Fungal strains belonging to the genera Alternaria, Cladosporium, Epicoccum, Fusarium, Mucor, Penicillium, Pestalotiopsis, and Trichoderma were isolated 
directly from visibly fouled concrete structures and used individually and in a mix to inoculate mortar tiles varying in cement composition, supplementary cementitious material additions, water-to-cement ratio, and surface roughness. A strong positive relationship was observed between the tile water-to-cement ratio and the amount of biofouling. However, the addition of supplementary cementitious materials, such as fly ash, blast furnace slag, silica fume or metakaolin did not significantly affect biofouling in the mixed fungal community or T. viride incubations. Blast furnace slag was added in varying amounts of $10 \%, 25 \%$, and $50 \%$, and the results indicated, that the slag had only a small antifungal effect [5].

In contrast, it has been observed [6] that ground granulated blast furnace slag (GBFS), as well as cements with GBFS content of $\geq 65 \mathrm{wt} \%$ possesses fungistatic properties. Therefore, fungistatic blast-furnace cements CEM III/ A 32,5 N (with a GBFS content of $65 \mathrm{wt} \%$ ), CEM III/ B 32,5 N, and CEM III/C 32,5 N can be produced for achieving long-term fungistatic protection [6]. Moreover, using GBFS as a concrete additive results in several advantageous concrete properties, such as a low hydration heat, high durability, low capillary porosity, high resistance to chloride penetration, sulphate, and thaumasite sulphate attack, and protection against alkali silica reaction [7].

Generally, metallurgical slags are classified into two types: ferrous slag, which include iron slag generated in blast furnace processes and steel slags, and non-ferrous slag generated by the production of non-ferrous metals (Cu, $\mathrm{Zn}, \mathrm{Pb}, \mathrm{Ni}$, etc.) [8]. Ferrous metallurgical slags are determined by the kind of furnace from which they are generated. Different slag types originate from iron- and steelmaking processes [9]. The main slag types produced from the iron- and steelmaking industries are classified as follows: (i) blast-furnace slags (ironmaking slags); (ii) steel-furnace slags (steelmaking and steel refining processes slags), further divided as follows: (a) basic-oxygen-furnace slag, (b) electric-arc-furnace slag, and (c) ladle furnace slag [9]. Metallurgical slags are widely utilized for many construction and civil engineering purposes according to European standards, such as EN 197-1, EN 413-1, EN 14216, EN 206, EN 15167-1, EN 12620, EN 13043, EN 13055-1, -2, EN 13139, EN 13242, EN 13383-1, EN 13450, EN 14227-1, -2, -5, -10, -12, -13, etc. Steel-furnace slags are produced in smaller quantities than blast-furnace slags and are less widely used. It is estimated that one-half to two-thirds of steel-furnace slags produced worldwide are used either by recycling or in road building applications, road bases, fill, asphalt aggregate, railroad ballast, as fertilizers, soil conditioning, raw material for cement manufacture, etc. In some cases, specific aging or weathering requirements are stipulated to hydrate $\mathrm{CaO}_{\text {free }}$ prior to use [10]. Different types of slag have different capabilities for recycling and reuse; ladle furnace slag has the lowest such capability. About $80 \%$ of ladle furnace slag is currently landfilled, taking into account the whole of the EU [11].

The article aims to study the antimicrobial efficiency of metallurgical slags for increasing their utilization in building materials and products, as well as for enlarging civil engineering applications with respect to higher biodeterioration resistance and sustainable development. Slag antimicrobial efficiency was determined by dilution methods in agar growth media, with the resulting concentrations of tested slags at 10,20,40, and $60 \%$, and these were then mutually compared and also compared with a commercial biocide based on antimicrobial silver Ag.

\section{Materials and Methods}

The following types of metallurgical slags were tested: granulated blast-furnace slags with specific surface areas, such as $340 \mathrm{~m}^{2} / \mathrm{kg}$ (S1a) and $520 \mathrm{~m}^{2} / \mathrm{kg}$ (S1b); air cooled blast-furnace slag (S2); demetallized steel slag (S3); calcareous ladle slag (S4); and copper slag (S5). Most of them were ground to the specific surface area of $400 \mathrm{~m}^{2} / \mathrm{kg}$, except for S1a and S1b. The chemical composition of samples was analysed by X-ray fluorescence analysis (XRF) according to EN 196-2 using a SPECTRO X-LAB 2000 apparatus (Kleve, Germany). The semi-quantitative chemical composition of the slags is introduced in Table 1. 
Table 1. The chemical composition (semi-quantitative analysis) of the tested metallurgical slags.

\begin{tabular}{|c|c|c|c|c|c|c|}
\hline Slag & Unit & S1a and S1b & S2 & S3 & S4 & S5 \\
\hline L.O.I ${ }^{1}$ & $(w t \%)$ & 0.95 & 0.09 & 6.02 & 5.32 & $+4.30^{2}$ \\
\hline $\mathrm{SiO}_{2}$ & $(w t \%)$ & 42.17 & 40.57 & 12.81 & 13.97 & 27.26 \\
\hline $\mathrm{Al}_{2} \mathrm{O}_{3}$ & $(w t \%)$ & 6.87 & 8.12 & 1.64 & 17.77 & 7.01 \\
\hline $\mathrm{Fe}_{2} \mathrm{O}_{3}$ & $(w t \%)$ & 0.32 & 2.81 & 29.78 & 1.90 & 46.64 \\
\hline $\mathrm{CaO}$ & $(w t \%)$ & 41.92 & 41.73 & 52.30 & 58.97 & 7.48 \\
\hline $\mathrm{TiO}_{2}$ & $(w t \%)$ & 0.42 & 0.11 & 0.34 & 0.14 & 0.21 \\
\hline $\mathrm{MgO}$ & $(w t \%)$ & 10.39 & 8.44 & 2.54 & 3.30 & 1.90 \\
\hline $\mathrm{K}_{2} \mathrm{O}$ & $(w t \%)$ & 0.60 & 0.72 & 0.04 & 0.06 & 0.40 \\
\hline $\mathrm{Na}_{2} \mathrm{O}$ & $(w t \%)$ & 0.17 & 0.19 & 0.07 & 0.07 & 1.07 \\
\hline $\mathrm{SO}_{3}$ & $(w t \%)$ & 1.84 & 2.39 & 0.28 & 1.98 & 0.15 \\
\hline $\mathrm{MnO}$ & $(w t \%)$ & 0.68 & 2.31 & 3.54 & 0.38 & 0.61 \\
\hline $\mathrm{P}_{2} \mathrm{O}_{5}$ & (wt \%) & 0.05 & 0.14 & 0.48 & 0.05 & 1.26 \\
\hline $\mathrm{Cl}$ & $(w t \%)$ & 0.0173 & 0.0112 & 0.0138 & 0.0017 & 0.0012 \\
\hline $\mathrm{V}$ & (ppm) & 27.0 & 32.0 & 298.0 & 54.0 & 41.0 \\
\hline $\mathrm{Cr}$ & (ppm) & 69.6 & 65.0 & 981.0 & 419.0 & 5740.0 \\
\hline $\mathrm{Co}$ & (ppm) & 21.1 & 21.5 & 98.0 & 37.6 & 307.0 \\
\hline $\mathrm{Ni}$ & (ppm) & 1.9 & 3.4 & 9.9 & 9.8 & 1893.0 \\
\hline $\mathrm{Cu}$ & (ppm) & 1.2 & 1.5 & 10.1 & 4.9 & 7273.0 \\
\hline $\mathrm{Zn}$ & (ppm) & 98.1 & 18.7 & 41.3 & 12.3 & $50,341.0$ \\
\hline As & (ppm) & 0.7 & 1.4 & 3.2 & 22.1 & 66.65 \\
\hline $\mathrm{Cd}$ & (ppm) & 11.6 & 12.0 & 24.3 & 22.0 & 5.0 \\
\hline $\mathrm{Sb}$ & (ppm) & 1.5 & 1.8 & 2.0 & 26.7 & 50.2 \\
\hline $\mathrm{Hg}$ & (ppm) & 2.9 & 1.9 & 6.6 & 4.2 & 28.5 \\
\hline $\mathrm{Tl}$ & (ppm) & 1.5 & 3.3 & 5.6 & 6.0 & 19.0 \\
\hline $\mathrm{Pb}$ & (ppm) & 4.0 & 17.6 & 3.2 & 7.5 & 9203.3 \\
\hline
\end{tabular}

Notes: ${ }^{1}$ L.O.I: Loss on ignition; ${ }^{2}$ Increment on ignition (caused by e.g., oxidation of metallic particles, sulphides, disulphides, sulphites etc.).

The mineralogical composition of the samples was determined by the XRD technique using a BRUKER AXS D8 Advance device (Karlsruhe, Germany). The identified mineralogical composition of the slags is as follows: $\mathrm{S} 1 \mathrm{a}$ and $\mathrm{S} 1 \mathrm{~b}-$ melilite (a solid solution of gehlenite $\mathrm{C}_{2} \mathrm{AS}$ and akermanite $\mathrm{C}_{2} \mathrm{MS}_{2}$ ); S2-melilite $\mathrm{C}_{2} \mathrm{AS}-\mathrm{C}_{2} \mathrm{MS}_{2}$, brownmillerite $\mathrm{C}_{4} \mathrm{AF}$, quartz $\mathrm{SiO}_{2}$; $\mathrm{S} 3$ - wüstite $\mathrm{FeO}$, brownmillerite $\mathrm{C}_{4} \mathrm{AF}$, free lime $\mathrm{CaO}$, portlandite $\mathrm{Ca}(\mathrm{OH})_{2}$, larnite $\beta-\mathrm{C}_{2} \mathrm{~S}$, quartz $\mathrm{SiO}_{2} ; \mathrm{S} 4$-free lime $\mathrm{CaO}$, larnite $\beta-\mathrm{C}_{2} \mathrm{~S}$, shanonite $\gamma-\mathrm{C}_{2} \mathrm{~S}$, gehlenite $\mathrm{C}_{2} \mathrm{AS}, \mathrm{C}_{3} \mathrm{~A}$, gypsum $\mathrm{CaSO}_{4} \cdot 2 \mathrm{H}_{2} \mathrm{O}$, quartz $\mathrm{SiO}_{2}$ and $\mathrm{S} 5$-fayalite $\mathrm{Fe}_{2} \mathrm{SiO}_{4}$, anortite $\mathrm{CAS}_{2}$, pyroxene type $\mathrm{CaAlAlSiO}$. Biostat is a commercial biocide admixture based on antimicrobial silver $\mathrm{Ag}$ bonding to an $\mathrm{Al}_{2} \mathrm{O}_{3}$ support $\left(\mathrm{Al}_{2} \mathrm{O}_{3} 99.62 \mathrm{wt} \%\right)$, with the efficient concentration of $\mathrm{Ag}$ at the level of $20 \mathrm{mg} / \mathrm{g}$. Biostat is added in a proportion of $0.5 \mathrm{wt} \%$ in the thin layer applications, such as rendering and plastering mortars and of $1.0 \mathrm{wt} \%$ in rough, coarse layer applications, such as masonry mortar and bricklaying, to achieve an antimicrobial environment.

\subsection{Determination of Free Calcium Oxide $\mathrm{CaO}_{\text {free }}$ Content in Ground Metallurgical Slags and $\mathrm{pH}$ of Water Leachates}

The determination of free calcium oxide $\mathrm{CaO}_{\text {free }}$ content in the metallurgical slags was performed using the hot ethylene glycol titration method. The slag sample was ground in the laboratory's vibratory mill to a fineness with particle size under $0.1 \mathrm{~mm}$ sieve. Then $1.0 \mathrm{~g}$ of the slag sample was diluted with $75 \mathrm{~mL}$ of ethylene glycol in a filter flask. Afterwards, the solution was heated for half an hour with occasional stirring and then washed with $50 \mathrm{~mL}$ of denatured ethanol. Approximately 2-3 drops of alpha-naphthol phthalein was added to the solution as an indicator. The solution was then titrated with $0.1 \mathrm{~N} \mathrm{HCl}$, and the titration continued until the colour changed from blue to colourless. The $\mathrm{CaO}_{\text {free }}$ content in the slag sample was calculated as follows: $w \mathrm{t} \% \mathrm{CaO}_{\text {free }}=$ (the volume of $0.1 \mathrm{~N}$ $\mathrm{HCl}$ used for the titration; in millilitres) $\times 0.28$. The $\mathrm{CaO}_{\text {free }}$ content in the slags is given in Table 2 . The ground slags were leached in distilled water at $20^{\circ} \mathrm{C}$ for $24 \mathrm{~h}$. The $\mathrm{pH}$ was determined in the slag 
water leachates by an Agilent Technologies $3200 \mathrm{P}$ pH Meter (Santa Clara, CA, USA) with an electrode reference system. The measured $\mathrm{pH}$ values of the water leachates are also shown in Table 2.

Table 2. The content of free calcium oxide $\mathrm{CaO}_{\text {free }}$ in the metallurgical slags and $\mathrm{pH}$ of the water leachates.

\begin{tabular}{ccccccc}
\hline Slag & Unit & S1a and S1b & S2 & S3 & S4 & S5 \\
\hline $\mathrm{CaO}$ free & $(\mathrm{wt} \%)$ & 0.00 & 0.06 & 0.95 & 3.30 & 0.00 \\
$\mathrm{pH}$ & - & 11.71 & 9.34 & 12.87 & 12.93 & 10.44 \\
\hline
\end{tabular}

No free lime $\mathrm{CaO}_{\text {free }}$ content was detected in slags $\mathrm{S1a}, \mathrm{S} 1 \mathrm{~b}$, and $\mathrm{S} 5$, very low $\mathrm{CaO}_{\text {free }}$ content in $\mathrm{S} 2$ and $\mathrm{S} 3$ and the highest $\mathrm{CaO}_{\text {free }}$ content was measured in $\mathrm{S} 4$ on the level of $3.30 \mathrm{wt} \%$, respectively. The $\mathrm{pH}$ values of the ground slag water leachates were in the range of 9.34-12.93. The highest $\mathrm{pH}$ values $>12$ were measured in leachates of slags $\mathrm{S} 3$ and $\mathrm{S} 4$, caused by the high free lime $\mathrm{CaO}_{\text {free }}$ content, and the lowest $\mathrm{pH}<11$ in leachates of slags S2 and S5. The water leached slags of S3 and S4 agglutinated into lumpy granules in water due to the hydration of free lime $\mathrm{CaO}_{\text {freee }}, \beta-\mathrm{C}_{2} \mathrm{~S}$, and in the case of $\mathrm{S} 4$ by the hydration of $\mathrm{C}_{3} \mathrm{~A}$ with gypsum, as well. The hydrated lumpy granules were mechanically disaggregated to increase the leaching surface contact.

\subsection{Determination of Antimicrobial Efficiency of Metallurgical Slags under In Vitro Conditions}

The antimicrobial activity of the metallurgical slags was tested on selected representatives of biodeteriogenic microflora, such as bacteria, yeasts, and filamentous fungi. Microbial strains (bacteria and filamentous fungi) used in this work were either from the Czech Collection of Microorganisms, T.G.Masaryk University, Brno, Czech Republic (CCM) or yeasts from the Collection of Microorganism of the Institute of Biochemistry and Microbiology, Slovak University of Technology, Bratislava, Slovak Republic. Following microorganisms were used: G-positive bacteria-Bacillus subtilis CCM 178, Staphylococcus aureus CCM 3958, Micrococcus luteus CCM 410; G-negative bacteria-Escherichia coli CCM 3988, Pseudomonas aeruginosa CCM 3630, Serratia marcescens CCM 8587; yeasts-Candida utilis-1a, Rhodotorula glutinis-1; microscopic filamentous fungi-Aspergillus niger CCM-F 384, Penicillium funiculosum CCM 8080, Chaetomium globosum CCM 8156, Alternaria alternate CCM F-128, Trichoderma viride CCM F-534, Cladosporium herbarum CCM F-534. Gram-positive bacteria and Gram-negative bacteria differ in the thickness and chemical structure of their cell walls and, thus, also in sensitivity to antibiotics and other antibacterial agents.

\subsubsection{Growth Media}

The growth media used were as follows:

1. Meat-peptone bouillon (broth) for inoculation of bacteria (containing in $1000 \mathrm{~mL}$ of distilled water, $5 \mathrm{~g}$ meat extract, $5 \mathrm{~g}$ peptone for bacteriology and $2.5 \mathrm{~g} \mathrm{NaCl}$, with the $\mathrm{pH}$ adjusted from 7.2 to 7.4$)$;

2. Meat-peptone agar for cultivation of bacteria (containing in $1000 \mathrm{~mL}$ of distilled water, $5 \mathrm{~g}$ meat extract, $5 \mathrm{~g}$ peptone for bacteriology, $2.5 \mathrm{~g} \mathrm{NaCl}$ and $20 \mathrm{~g}$ agar, with the $\mathrm{pH}$ adjusted from 7.2 to 7.4);

3. Sabouraud's glucose bouillon (broth) for inoculation of yeasts (containing in $1000 \mathrm{~mL}$ of distilled water, $20 \mathrm{~g}$ glucose and $10 \mathrm{~g}$ peptone for bacteriology, with the $\mathrm{pH}$ adjusted to 6.5);

4. Malt agar for cultivation of yeasts and filamentous fungi (containing in $1000 \mathrm{~mL}$ of distilled water, $60 \mathrm{~g}$ malt extract and $20 \mathrm{~g}$ agar, with the $\mathrm{pH}$ adjusted to 6.5).

\subsubsection{Solutions}

For diluting the inoculum of bacteria and yeasts, saline solution $(0.85 \% \mathrm{NaCl})$ was used, and for preparation of the spore suspension (filamentous fungi-moulds), a $0.1 \%$ water solution of Tween 80 was used. 


\subsubsection{Preparation of the Inoculum of Bacteria and Yeasts}

A total of $25 \mathrm{~mL}$ of meat-peptone bouillon (broth) in a $100 \mathrm{~mL}$ Erlenmeyer flask was inoculated with a three-day-old culture of model bacteria using a bacterial loop, and $25 \mathrm{~mL}$ of Sabouraud's glucose bouillon (broth) in a $100 \mathrm{~mL}$ Erlenmeyer flask was inoculated with a three-day-old culture of yeasts using an inoculation loop. The microorganism cultures were incubated for $15 \mathrm{~h}$ at $30{ }^{\circ} \mathrm{C}$ using shaking apparatus (at a vibration frequency $4 \mathrm{~Hz}$ ). The grown microorganism cultures were aseptically filtered through three-ply gauze in order to remove possible clusters of cells. The obtained cell suspensions were diluted 100-fold with sterile saline (aqueous physiological solution) and were used for inoculation of the growth media (the cells concentration was $10^{6}$ cells per $\mathrm{mL}$ ) in order to determine the antibacterial and anti-yeast activity of the slag samples, respectively.

\subsubsection{Preparation of Spore Suspension of Filamentous Fungi}

A total of $8 \mathrm{~mL} 0.1 \%$ water solution of Tween 80 was aseptically added to the sporulated cultures of filamentous fungi, which had been cultivated on slant malt agar for 21 days. Spores from mycelium were loosened by bacterial loop, and filtered as above. The filtered spore suspension was diluted by sterile saline (the spores concentration was $2 \times 10^{7}$ spores per $\mathrm{mL}$ ) and used for inoculation of the growth media in order to determine the antifungal activity of the slag samples.

\subsubsection{Determination of Antimicrobial Activity}

Meat-peptone bouillon for inoculation of bacteria, meat-peptone agar for cultivation of bacteria, Sabouraud's glucose bouillon for inoculation of yeasts and malt agar for cultivation of yeasts and filamentous fungi were used as growth media. Saline solution was used for diluting the inoculum of bacteria and yeasts, and a water solution of Tween 80 was used for preparation of the spore suspension. Sterilization of growth media and solutions was realized in the laboratory autoclave at $120{ }^{\circ} \mathrm{C}$ for $20 \mathrm{~min}$. The tests were performed in the laboratory incubator at temperatures of $30^{\circ} \mathrm{C}$ for bacteria, $28{ }^{\circ} \mathrm{C}$ for yeasts and $25^{\circ} \mathrm{C}$ for filamentous fungi at a relative humidity of $95 \%$. Antimicrobial activity was determined by dilution methods in agar growth media, so that the resulting concentration of tested slags in growth media was 10,20,40, and 60\%; further, the concentration of Biostat in growth media was 1.0 and $0.5 \%$, respectively. The $\mathrm{pH}$ of the growth media with the addition of the slags was strongly alkaline ( $\mathrm{pH} 11$ ); thus, half the samples of each slag was tested at this $\mathrm{pH}$, and the second half of the samples was tested at a modified $\mathrm{pH}$ (bacteria $\mathrm{pH} 7.2$, yeasts, and filamentous fungi $\mathrm{pH}$ 6.6). The first half of the samples with the original $\mathrm{pH}$ represented real conditions for growth of microorganisms in concrete; the second half of the samples with a modified $\mathrm{pH}$ represented optimal conditions for growth of the microorganisms in vitro.

After sterilization, meat-peptone agar and malt agar with added slag samples and Biostat (at original $\mathrm{pH}$ and modified $\mathrm{pH}$ ) were cooled down to $60^{\circ} \mathrm{C}$. The slag samples and Biostat were equally dispersed throughout growth media and subsequently they were divided and $6 \mathrm{~mL}$ of each was placed in the Petri dishes $\varnothing 60.0 \mathrm{~mm}$. Sterile paper discs $(\varnothing 5.0 \mathrm{~mm})$ were placed on the surface of solidified growth media, which were inoculated by $5 \mu \mathrm{L}$ from spore suspension of model filamentous fungi on malt agar. The inoculation of bacteria and yeasts was done by direct pipetting the suspension on the surface of agarized media. Each $10 \mu \mathrm{L}$ of suspensions were pipetted from the model bacteria onto meat-peptone agar or model yeasts on the malt agar.

The microorganisms were incubated in a thermostat at temperatures of $30{ }^{\circ} \mathrm{C}$ for bacteria, $28{ }^{\circ} \mathrm{C}$ for yeasts, $25^{\circ} \mathrm{C}$ for filamentous fungi at a relative humidity of $95 \%$ for four days. The growth intensity of bacteria and yeasts was compared with the growth of bacteria and yeasts in the control growth media without slags. The growth of filamentous fungi in the presence of slags was monitored by the measurement of average diameter of growing colony at regular time intervals and was compared with the filamentous fungi growth in the control growth media without slags. In the case that no filamentous fungi growth with the presence of slags was observed, the paper discs with spores were transferred 
on fresh growth media. After $96 \mathrm{~h}$ incubation at $25^{\circ} \mathrm{C}$, the inhibiting effect of slags was inspected: fungistatic (spores germinate and subsequently the mycelium grows broader) and fungicidal-lethal (fungi do not grow; they are dead).

\section{Results}

Firstly, the antimicrobial activity of individual slag samples on selected representatives of biodeteriogenic microflora was determined; subsequently the antimicrobial efficiency of individual slags was mutually compared. The test results on the antimicrobial efficiency of the individual slags are given in Tables 3-5. The antimicrobial efficiencies of slags regarding inhibition of growth of selected bacteria are given in Table 3; the antimicrobial efficiencies of slags regarding inhibition of growth of selected yeasts are given in Table 4; and the antimicrobial efficiencies of slags regarding inhibition of growth of selected filamentous fungi are given in Table 5, respectively. The antimicrobial efficiencies of the metallurgical slags are compared with the antimicrobial efficiencies of the commercial biocide admixture Biostat. The growth extent of selected bacteria and yeasts is expressed by mathematical signs $(-,+,++,+++)$, and the degree of growth of selected filamentous fungi is expressed relatively by the percentage (\%) of the sample surface covered by fungi colonies (measured against a $\mathrm{K}$-control growth media without slags; with the expression of the c-fungicidal effect and s-fungistatic effect). The tests were also carried out at $\mathrm{A}$-alkaline $\mathrm{pH}$ of growth media and $\mathrm{N}$-neutral $\mathrm{pH}$ of growth media.

\subsection{Antimicrobial Efficiency of Metallurgical Slags with Growth of Selected Bacteria}

The results of determining the antibacterial efficiency of the individual slag samples and Biostat on the selected model Gram-positive bacteria $\left(\mathrm{G}^{+}\right)$and Gram-negative bacteria $\left(\mathrm{G}^{-}\right)$are given in Table 3 . Based on the obtained results, it can be stated that the inhibitory effect of the slag samples differs. Slag S4, which intensely inhibited growth of $\mathrm{G}^{+}$and also $\mathrm{G}^{-}$bacteria, had the highest antibacterial activity, which was also proven at the lowest concentration of slag S4: 10\% in growth media. The bacteria, except $M$. luteus, did not grow at higher concentrations of slag $\mathrm{S} 4$ in growth media, whereas the $\mathrm{pH}$ values of the growth media (alkaline, neutral) did not affect the inhibition intensity of bacterial growth.

The growth of $\mathrm{G}^{+}$bacteria S. aureus and B. subtilis was inhibited in the presence of slag S3. The growth of $\mathrm{G}^{+}$bacteria $S$. aureus and B. subtilis was inhibited by slag $\mathrm{S} 3$ in growth media as early as at a concentration of $10 \%$, and at higher concentrations growth was completely inhibited. However, slag S3 did not affect the growth of $\mathrm{G}^{-}$bacteria, except for $E$. coli, at the highest concentration used $(60 \%)$. Inhibition of bacterial growth in the presence of slag S2 was more intensive in the alkaline $\mathrm{pH}$ of growth media. The complete inhibition of the growth of $\mathrm{G}^{+}$bacteria $S$. aureus and B. subtilis was detected with slag S2 at concentrations of 20,40, and $60 \%$ in growth media and, inhibition of growth of $\mathrm{G}^{-}$bacteria E. coli, S. marcescens and P. aeruginosa was detected at a slag S2 concentration of $60 \%$ in growth media. Slag S2 only completely inhibited the growth of $B$. subtilis at a neutral $\mathrm{pH}$ of growth media; however, it did so at all tested concentrations. Slag S1a caused total inhibition of B. subtilis growth at concentrations of 40 and $60 \%$ in growth media at both a neutral and alkaline $\mathrm{pH}$. The growth of S. aureus under conditions of $60 \%$ concentration of slag S1a in growth media at a neutral $\mathrm{pH}$ was completely inhibited.

A 40 and $60 \%$ concentration of slag S1b in growth media at neutral as well as alkaline $\mathrm{pH}$ led to total inhibition of the growth of B. subtilis. No growth of E. coli was observed at a slag S1b concentration of $60 \%$ in growth media at neutral pH. Slag S5 did not significantly affect the growth of the model bacteria. Slags S1a, S1b, S2 and S5 caused a change in S. marcescens growth at alkaline $\mathrm{pH}$. The bacteria S. marcescens under these circumstances lost its red pigment and grew as a white colony.

Biostat at a concentration of $1.0 \%$ in growth media caused $100 \%$ inhibition of the growth of all model bacteria at neutral and alkaline $\mathrm{pH}$. Only slight or no bacterial growth was observed at a Biostat concentration of $0.5 \%$ in growth media, while $\mathrm{pH}$ had no effect on their growth. Based on the obtained results, it can be stated that the antibacterial efficiency of the individual slag samples decreased in the order: $\mathrm{S} 4>\mathrm{S} 3>\mathrm{S} 2>$ 
$\mathrm{S} 1 \mathrm{a}=\mathrm{S} 1 \mathrm{~b}>\mathrm{S} 5$. An overview of the testing arrangement in Petri dishes regarding the inhibition of bacteria growth in the presence of slag $\mathrm{S} 4$ and alkaline $\mathrm{pH}$ of growth media is shown in Figure 1A.

Table 3. Antibacterial efficiency of metallurgical slags regarding inhibition of growth of selected bacteria.

\begin{tabular}{|c|c|c|c|c|c|c|}
\hline S1aA & M. luteus & S. aureus & B. subtilis & E. coli & S. marcescens & P. aeruginosa \\
\hline $10 \%$ & +++ & +++ & +++ & +++ & +++ & +++ \\
\hline $20 \%$ & +++ & +++ & +++ & +++ & +++ & +++ \\
\hline $40 \%$ & +++ & ++ & - & ++ & +++ white & +++ \\
\hline $60 \%$ & +++ & ++ & - & + & ++white & +++ \\
\hline S1aN & M. luteus & S. aureus & B. subtilis & E. coli & S. marcescens & P. aeruginosa \\
\hline $10 \%$ & +++ & +++ & +++ & +++ & +++ & +++ \\
\hline $20 \%$ & +++ & +++ & +++ & +++ & +++ & +++ \\
\hline $40 \%$ & +++ & +++ & - & +++ & +++ & +++ \\
\hline $60 \%$ & +++ & - & - & +++ & +++ & +++ \\
\hline $\mathrm{S} 1 \mathrm{bA}$ & M. luteus & S. aureus & B. subtilis & E. coli & S. marcescens & P. aeruginosa \\
\hline $10 \%$ & +++ & +++ & +++ & +++ & +++ white & +++ \\
\hline $20 \%$ & +++ & +++ & +++ & +++ & +++ white & +++ \\
\hline $40 \%$ & +++ & +++ & - & ++ & +++ white & +++ \\
\hline $60 \%$ & +++ & +++ & - & + & ++white & +++ \\
\hline $\mathrm{S} 1 \mathrm{bN}$ & M. luteus & S. aureus & B. subtilis & E. coli & S. marcescens & P. aeruginosa \\
\hline $10 \%$ & +++ & +++ & +++ & +++ & +++ & +++ \\
\hline $20 \%$ & +++ & +++ & +++ & +++ & +++ & +++ \\
\hline $40 \%$ & +++ & +++ & - & +++ & +++ & +++ \\
\hline $60 \%$ & +++ & ++ & - & - & +++ & +++ \\
\hline S2A & M. luteus & S. aureus & B. subtilis & E. coli & S. marcescens & P. aeruginosa \\
\hline $10 \%$ & ++ & + & + & ++ & ++white & ++ \\
\hline $20 \%$ & ++ & - & - & ++ & ++white & ++ \\
\hline $40 \%$ & ++ & - & - & ++ & ++white & ++ \\
\hline $60 \%$ & - & - & - & - & - & - \\
\hline $\mathrm{S} 2 \mathrm{~N}$ & M. luteus & S. aureus & B. subtilis & E. coli & S. marcescens & P. aeruginosa \\
\hline $10 \%$ & +++ & +++ & - & +++ & +++ & +++ \\
\hline $20 \%$ & +++ & +++ & - & +++ & +++ & +++ \\
\hline $40 \%$ & +++ & +++ & - & +++ & +++ & +++ \\
\hline $60 \%$ & +++ & +++ & - & ++ & ++ & ++ \\
\hline S3A & M. luteus & S. aureus & B. subtilis & E. coli & S. marcescens & P. aeruginosa \\
\hline $10 \%$ & +++ & + & + & +++ & +++ & +++ \\
\hline $20 \%$ & +++ & - & - & +++ & +++ & +++ \\
\hline $40 \%$ & +++ & - & - & ++ & +++ & +++ \\
\hline $60 \%$ & +++ & - & - & + & +++ & +++ \\
\hline S3N & M. luteus & S. aureus & B. subtilis & E. coli & S. marcescens & P. aeruginosa \\
\hline $10 \%$ & +++ & ++ & ++ & +++ & +++ & +++ \\
\hline $20 \%$ & +++ & - & - & +++ & +++ & +++ \\
\hline $40 \%$ & +++ & - & - & +++ & +++ & +++ \\
\hline $60 \%$ & +++ & - & - & - & +++ & +++ \\
\hline $\mathrm{S} 4 \mathrm{~A}$ & M. luteus & S. aureus & B. subtilis & E. coli & S. marcescens & P. aeruginosa \\
\hline $10 \%$ & ++ & ++ & ++ & ++ & + & - \\
\hline $20 \%$ & + & - & - & - & - & - \\
\hline $40 \%$ & + & - & - & - & - & - \\
\hline $60 \%$ & - & - & - & - & - & - \\
\hline $\mathrm{S} 4 \mathrm{~N}$ & M. luteus & S. aureus & B. subtilis & E. coli & S. marcescens & P. aeruginosa \\
\hline $10 \%$ & + & + & + & + & + & - \\
\hline $20 \%$ & + & - & - & - & - & - \\
\hline $40 \%$ & + & - & - & - & - & - \\
\hline $60 \%$ & - & - & - & - & - & - \\
\hline
\end{tabular}


Table 3. Cont.

\begin{tabular}{ccccccc}
\hline S5A & M. luteus & S. aureus & B. subtilis & E. coli & S. marcescens & P. aeruginosa \\
\hline $10 \%$ & +++ & +++ & +++ & +++ & +++ & +++ \\
$20 \%$ & +++ & +++ & +++ & +++ & +++ & +++ \\
$40 \%$ & +++ & +++ & + & +++ & +++ white & +++ \\
$60 \%$ & +++ & +++ & + & +++ & ++ white & +++ \\
\hline S5N & M. luteus & S. aureus & B. subtilis & E. coli & S. marcescens & P. aeruginosa \\
\hline $10 \%$ & +++ & +++ & +++ & +++ & +++ & +++ \\
$20 \%$ & +++ & +++ & +++ & +++ & +++ & +++ \\
$40 \%$ & +++ & +++ & +++ & +++ & +++ & +++ \\
$60 \%$ & ++ & ++ & ++ & ++ & ++ & ++ \\
\hline BiostatA & M. luteus & S. aureus & B. subtilis & E. coli & S. marcescens & P. aeruginosa \\
\hline $0.5 \%$ & ++ & - & + & + & + & + \\
$1 \%$ & - & - & - & - & - & - \\
\hline BiostatN & M. luteus & S. aureus & B. subtilis & E. coli & S. marcescens & P. aeruginosa \\
\hline $0.5 \%$ & + & - & - & - & + & - \\
$1 \%$ & - & - & - & - & - & - \\
\hline
\end{tabular}

Notes: - no growth of bacteria; + the growth of bacteria is negligible; ++ the growth of bacteria is gradual; +++ the growth of bacteria is intensive comparable with the control growth media; A-alkaline $\mathrm{pH}$ of growth media; $\mathrm{N}$-neutral $\mathrm{pH}$ of growth media; white-the colony of Serratia marcescens-loss of red pigment by metallurgical slag impact.

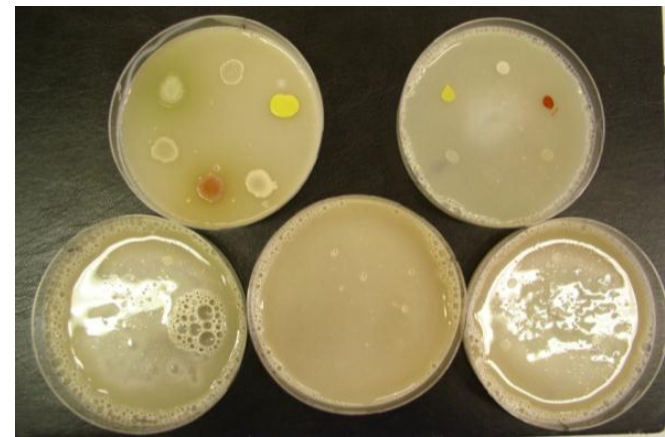

(A)

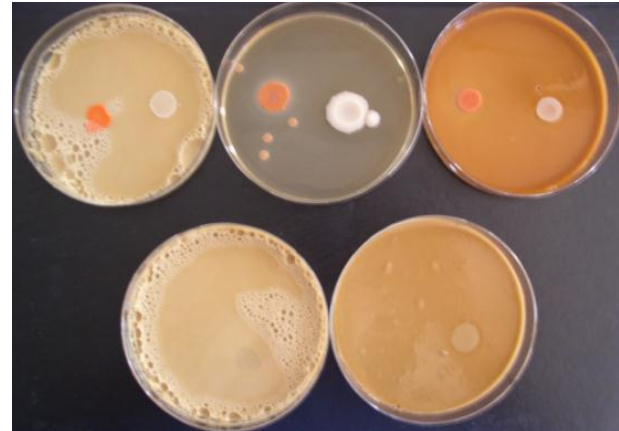

(B)

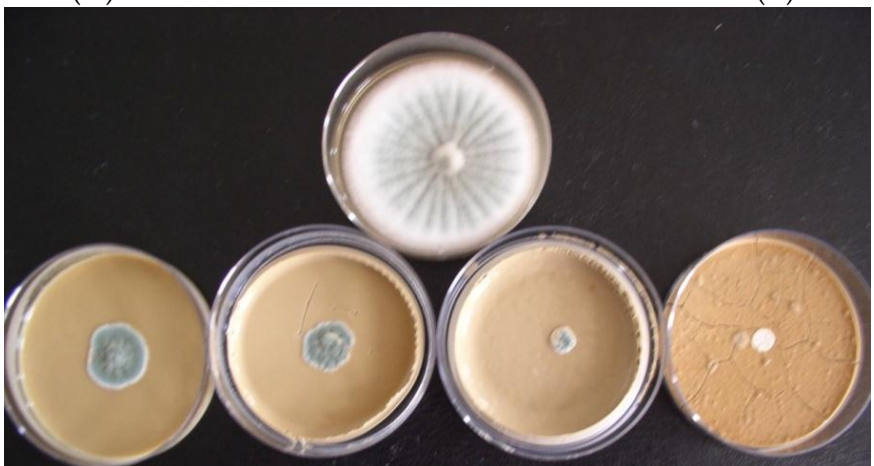

(C)

Figure 1. View of the testing arrangement in Petri dishes regarding the growth inhibition of selected representatives of biodeteriogenic microflora in the presence of tested slags: (A) inhibition of bacteria growth in the presence of slag S4 with alkaline $\mathrm{pH}$ of the growth media (upper line from left: control (no slag), slag S4-10\%; lower line from left: slag S4-20\%, 40\%, 60\%); (B) inhibition of yeasts growth in the presence of slag S1a at neutral $\mathrm{pH}(\mathrm{N})$ and alkaline $\mathrm{pH}(\mathrm{A})$ of the growth media (upper line from left: slag S1a (A)—10\%, control (no slag), slag S1a (N) - 10\%; lower line from left: slag S1a (A) - 60\%, S1a (N) -60\%); and $(\mathrm{C})$ inhibition of Penicillium funiculosum growth in the presence of slag S1a at alkaline $\mathrm{pH}(\mathrm{A})$ of the growth media (upper line: control (no slag), lower line from left: slag S1a (A) - 10\%, 20\%, 40\%, 60\%). 


\subsection{Antimicrobial Efficiency of Metallurgical Slags regarding Growth of Selected Yeasts}

The results of determining the anti-yeast efficiency of the individual slag samples and Biostat on the selected model yeasts are given in Table 4. Slag S4 possessed the highest anti-yeast activity. Growth of all model yeasts was completely inhibited at concentration as low as 10\% of slag S4, at both alkaline and neutral $\mathrm{pH}$ of the growth media. Slags S1a, S1b, and S3 caused total inhibition of the growth of all model yeasts from a concentration of $20 \%$ in growth media at alkaline and neutral $\mathrm{pH}$, as well. The growth of the model yeasts was intensively reduced in the presence of slag S2 at concentrations of 40 and $60 \%$ in growth media. Slag S5 partially inhibited the growth of the model yeasts; however, total inhibition of the growth of yeasts was not observed even at the highest concentration of $60 \%$ in growth media.

Biostat at a concentration of $1.0 \%$ in growth media caused complete inhibition of growth of all model yeasts at alkaline, as well as neutral, $\mathrm{pH}$. However, the intensive growth of yeasts was observed at Biostat concentration of $0.5 \%$ in growth media, and so Biostat did not demonstrate an inhibiting effect on the growth of yeasts at $0.5 \%$ concentration. Based on the measured results, the anti-yeast efficiency of the individual slag samples decreased in the order: $\mathrm{S} 4>\mathrm{S} 1 \mathrm{a}=\mathrm{S} 1 \mathrm{~b}=\mathrm{S} 3>\mathrm{S} 2>\mathrm{S} 5$. An overview of the testing arrangement in Petri dishes regarding the inhibition of yeasts growth in the presence of slag S1a in neutral $\mathrm{pH}(\mathrm{N})$ and alkaline $\mathrm{pH}(\mathrm{A})$ of growth media is shown in Figure 1B.

Table 4. Growth inhibition of selected yeasts by metallurgical slags.

\begin{tabular}{ccccccccc}
\hline S1aA & C. utilis & R. glutinis & S1aN & C. utilis & R. glutinis & S1bA & C. utilis & R. glutinis \\
\hline $10 \%$ & +++ & +++ & $10 \%$ & +++ & +++ & $10 \%$ & + & + \\
$20 \%$ & - & - & $20 \%$ & - & - & $20 \%$ & - & - \\
$40 \%$ & - & - & $40 \%$ & - & - & $40 \%$ & - & - \\
$60 \%$ & - & - & $60 \%$ & - & - & $60 \%$ & - & - \\
\hline S1bN & C. utilis & R. glutinis & S2A & C. utilis & R. glutinis & S2N & C. utilis & R. glutinis \\
\hline $10 \%$ & + & + & $10 \%$ & +++ & +++ & $10 \%$ & +++ & +++ \\
$20 \%$ & - & - & $20 \%$ & +++ & ++ & $20 \%$ & +++ & +++ \\
$40 \%$ & - & - & $40 \%$ & - & + & $40 \%$ & + & + \\
$60 \%$ & - & - & $60 \%$ & - & + & $60 \%$ & - & + \\
\hline S3A & C. utilis & R. glutinis & S3N & C. utilis & R. glutinis & S4A & C. utilis & R. glutinis \\
\hline $10 \%$ & - & + & $10 \%$ & - & +++ & $10 \%$ & - & - \\
$20 \%$ & - & - & $20 \%$ & - & - & $20 \%$ & - & - \\
$40 \%$ & - & - & $40 \%$ & - & - & $40 \%$ & - & - \\
$60 \%$ & - & - & $60 \%$ & - & - & $60 \%$ & - & - \\
\hline S4N & C. utilis & R. glutinis & S5A & C. utilis & R. glutinis & S5N & C. utilis & R. glutinis \\
\hline $10 \%$ & - & - & $10 \%$ & +++ & +++ & $10 \%$ & +++ & +++ \\
$20 \%$ & - & - & $20 \%$ & ++ & ++ & $20 \%$ & ++ & +++ \\
$40 \%$ & - & - & $40 \%$ & ++ & ++ & $40 \%$ & ++ & +++ \\
$60 \%$ & - & - & $60 \%$ & + & + & $60 \%$ & ++ & ++ \\
\hline BiostatA & C. utilis & R. glutinis & BiostatN & C. utilis & R. glutinis & & & + \\
\hline $0.5 \%$ & +++ & +++ & $0.5 \%$ & +++ & +++ & & & + \\
$1 \%$ & - & - & $1 \%$ & - & - & & \\
\hline
\end{tabular}

Notes: - no growth of yeasts; + the growth of yeasts is negligible; ++ the growth of yeasts is gradual; +++ the growth of yeasts is intensive comparable with the control growth media; A-alkaline $\mathrm{pH}$ of growth media; $\mathrm{N}$-neutral $\mathrm{pH}$ of growth media.

\subsection{Antimicrobial Efficiency of Metallurgical Slags regarding the Growth of Selected Filamentous Fungi}

The antifungal efficiency values of the individual slag samples and Biostat on the selected model filamentous fungi are given in Table 5. Growth of Alternaria alternata was most intensively inhibited by slag S4. Total inhibition of $A$. alternata growth was observed at concentrations of 40 and $60 \%$ of slag $\mathrm{S} 4$ in growth media at neutral as well as alkaline $\mathrm{pH}$, particularly at a concentration of $20 \%$ in 
growth media at alkaline $\mathrm{pH}$. Slag S4 even had a fungicidal (lethal) effect on the fungal spores of A. alternata at a concentration of $60 \%$ in growth media at neutral $\mathrm{pH}$, while slag $\mathrm{S} 1 \mathrm{~b}$ hindered the growth of $A$. alternata at a concentration of $60 \%$ in growth media at neutral as well as alkaline $\mathrm{pH}$. Slags S1a and S3 completely inhibited A. alternata growth at a concentration of $60 \%$ in growth media, but only at neutral pH of the growth media. Slag S2 at concentrations of 40 and $60 \%$, and slag S5 at a concentration of $60 \%$ in growth media, partially inhibited the growth of model A. alternata. Based on a comparison of growth intensity of A. alternata in the presence of the tested slags, the sequence of decreasing inhibition efficiency of the individual slags was in the order: $\mathrm{S} 4>\mathrm{S} 1 \mathrm{~b}>\mathrm{S} 1 \mathrm{a}=\mathrm{S} 3>\mathrm{S} 2>\mathrm{S} 5$.

Table 5. Antifungal efficiency of metallurgical slags regarding inhibition of growth of selected filamentous fungi.

\begin{tabular}{|c|c|c|c|c|c|c|}
\hline \multirow{2}{*}{$\begin{array}{c}\text { Sample } \\
\text { S1aA }\end{array}$} & \multicolumn{6}{|c|}{ Growth of Selected Filamentous Fungi (\%) } \\
\hline & A. alternata & P. funiculosum & A. niger & T. viride & C. herbarum & Ch. globosum \\
\hline $10 \%$ & 90 & 30 & $0 \mathrm{~s}$ & $0 \mathrm{~s}$ & 88 & 72 \\
\hline $20 \%$ & 78 & 24 & $0 \mathrm{~s}$ & $0 \mathrm{~s}$ & 80 & 20 \\
\hline $40 \%$ & 50 & $0 \mathrm{~s}$ & $0 \mathrm{~s}$ & $0 \mathrm{~s}$ & 60 & $0 \mathrm{~s}$ \\
\hline $60 \%$ & 50 & $0 \mathrm{~s}$ & $0 \mathrm{~s}$ & $0 \mathrm{~s}$ & 40 & $0 \mathrm{c}$ \\
\hline $\mathrm{K}$ & 100 & 100 & 100 & 100 & 100 & 100 \\
\hline S1aN & A. alternata & P. funiculosum & A. niger & T. viride & C. herbarum & Ch. globosum \\
\hline $10 \%$ & 90 & 30 & $0 \mathrm{~s}$ & $0 \mathrm{~s}$ & 88 & 72 \\
\hline $20 \%$ & 60 & 24 & $0 \mathrm{~s}$ & $0 \mathrm{~s}$ & 80 & 20 \\
\hline $40 \%$ & 30 & $0 \mathrm{~s}$ & $0 \mathrm{~s}$ & $0 \mathrm{~s}$ & 20 & $0 \mathrm{~s}$ \\
\hline $60 \%$ & $0 \mathrm{~s}$ & $0 \mathrm{~s}$ & $0 \mathrm{~s}$ & $0 \mathrm{~s}$ & $0 \mathrm{~s}$ & $0 \mathrm{c}$ \\
\hline $\mathrm{K}$ & 100 & 100 & 100 & 100 & 100 & 100 \\
\hline S1bA & A. alternata & P. funiculosum & A. niger & T. viride & C. herbarum & Ch. globosum \\
\hline $10 \%$ & 80 & 22 & $0 \mathrm{~s}$ & $0 \mathrm{~s}$ & 80 & 72 \\
\hline $20 \%$ & 60 & 14 & $0 \mathrm{~s}$ & $0 \mathrm{~s}$ & 40 & 60 \\
\hline $40 \%$ & 30 & 10 & $0 \mathrm{~s}$ & $0 \mathrm{~s}$ & 40 & 50 \\
\hline $60 \%$ & $0 \mathrm{~s}$ & 0 & $0 \mathrm{~s}$ & $0 \mathrm{~s}$ & $0 \mathrm{~s}$ & 10 \\
\hline $\mathrm{K}$ & 100 & 100 & 100 & 100 & 100 & 100 \\
\hline S1bN & A. alternata & P. funiculosum & A. niger & T. viride & C. herbarum & Ch. globosum \\
\hline $10 \%$ & 40 & 30 & $0 \mathrm{~s}$ & $0 \mathrm{~s}$ & 80 & 72 \\
\hline $20 \%$ & 40 & 14 & $0 \mathrm{~s}$ & $0 \mathrm{~s}$ & 60 & 60 \\
\hline $40 \%$ & 40 & 10 & $0 \mathrm{~s}$ & $0 \mathrm{~s}$ & 60 & 40 \\
\hline $60 \%$ & $0 \mathrm{~s}$ & $0 \mathrm{~s}$ & $0 \mathrm{~s}$ & $0 \mathrm{~s}$ & $0 \mathrm{~s}$ & 10 \\
\hline $\mathrm{K}$ & 100 & 100 & 100 & 100 & 100 & 100 \\
\hline S2A & A. alternata & P. funiculosum & A. niger & T. viride & C. herbarum & Ch. globosum \\
\hline $10 \%$ & 80 & 30 & $0 \mathrm{~s}$ & $0 \mathrm{~s}$ & 80 & 80 \\
\hline $20 \%$ & 70 & 26 & $0 \mathrm{~s}$ & $0 \mathrm{~s}$ & 80 & 60 \\
\hline $40 \%$ & 54 & 20 & $0 \mathrm{~s}$ & $0 \mathrm{~s}$ & 60 & 40 \\
\hline $60 \%$ & 52 & 15 & $0 \mathrm{~s}$ & $0 \mathrm{~s}$ & 60 & 40 \\
\hline $\mathrm{K}$ & 100 & 100 & 100 & 100 & 100 & 100 \\
\hline S2N & A. alternata & P. funiculosum & A. niger & T. viride & C. herbarum & Ch. globosum \\
\hline $10 \%$ & 80 & 40 & $0 \mathrm{~s}$ & $0 \mathrm{~s}$ & 100 & 70 \\
\hline $20 \%$ & 72 & 30 & $0 \mathrm{~s}$ & $0 \mathrm{~s}$ & 80 & 60 \\
\hline $40 \%$ & 64 & 24 & $0 \mathrm{~s}$ & $0 \mathrm{~s}$ & 70 & 60 \\
\hline $60 \%$ & 54 & 20 & $0 \mathrm{~s}$ & $0 \mathrm{~s}$ & 60 & 50 \\
\hline K & 100 & 100 & 100 & 100 & 100 & 100 \\
\hline S3A & A. alternata & P. funiculosum & A. niger & T. viride & C. herbarum & Ch. globosum \\
\hline $10 \%$ & 80 & 20 & $0 \mathrm{~s}$ & $0 \mathrm{~s}$ & 52 & 80 \\
\hline $20 \%$ & 70 & 10 & $0 \mathrm{~s}$ & $0 \mathrm{~s}$ & 40 & 75 \\
\hline $40 \%$ & 40 & $0 \mathrm{~s}$ & $0 \mathrm{~s}$ & $0 \mathrm{~s}$ & 20 & 60 \\
\hline $60 \%$ & 20 & $0 \mathrm{~s}$ & $0 \mathrm{~s}$ & $0 \mathrm{~s}$ & $0 \mathrm{~s}$ & $0 \mathrm{~s}$ \\
\hline K & 100 & 100 & 100 & 100 & 100 & 100 \\
\hline S3N & A. alternata & P. funiculosum & A. niger & T. viride & C. herbarum & Ch. globosum \\
\hline $10 \%$ & 60 & 10 & $0 \mathrm{~s}$ & $0 \mathrm{~s}$ & 60 & 80 \\
\hline $20 \%$ & 40 & $0 \mathrm{~s}$ & $0 \mathrm{~s}$ & $0 \mathrm{~s}$ & 40 & 70 \\
\hline $40 \%$ & 32 & $0 \mathrm{~s}$ & $0 \mathrm{~s}$ & $0 \mathrm{~s}$ & 28 & 60 \\
\hline $60 \%$ & $0 \mathrm{~s}$ & $0 \mathrm{~s}$ & $0 \mathrm{~s}$ & $0 \mathrm{~s}$ & $0 \mathrm{~s}$ & $0 \mathrm{~s}$ \\
\hline $\mathrm{K}$ & 100 & 100 & 100 & 100 & 100 & 100 \\
\hline
\end{tabular}


Table 5. Cont.

\begin{tabular}{|c|c|c|c|c|c|c|}
\hline \multirow{2}{*}{$\begin{array}{c}\text { Sample } \\
\text { S4A }\end{array}$} & \multicolumn{6}{|c|}{ Growth of Selected Filamentous Fungi (\%) } \\
\hline & A. alternata & P. funiculosum & A. niger & T. viride & C. herbarum & Ch. globosum \\
\hline $10 \%$ & 70 & $0 \mathrm{~s}$ & $0 \mathrm{~s}$ & $0 \mathrm{~s}$ & 60 & $0 \mathrm{~s}$ \\
\hline $20 \%$ & $0 \mathrm{~s}$ & $0 \mathrm{~s}$ & $0 \mathrm{~s}$ & $0 \mathrm{~s}$ & $0 \mathrm{~s}$ & $0 \mathrm{~s}$ \\
\hline $40 \%$ & $0 \mathrm{~s}$ & $0 \mathrm{~s}$ & $0 \mathrm{~s}$ & $0 \mathrm{~s}$ & $0 \mathrm{~s}$ & $0 \mathrm{~s}$ \\
\hline $60 \%$ & $0 \mathrm{~s}$ & $0 \mathrm{~s}$ & $0 \mathrm{~s}$ & $0 \mathrm{c}$ & $0 \mathrm{~s}$ & $0 \mathrm{c}$ \\
\hline $\mathrm{K}$ & 100 & 100 & 100 & 100 & 100 & 100 \\
\hline S4N & A. alternata & P. funiculosum & A. niger & T. viride & C. herbarum & Ch. globosum \\
\hline $10 \%$ & 20 & 20 & $0 \mathrm{~s}$ & $0 \mathrm{~s}$ & $0 \mathrm{~s}$ & $0 \mathrm{~s}$ \\
\hline $20 \%$ & 10 & 10 & $0 \mathrm{~s}$ & $0 \mathrm{~s}$ & $0 \mathrm{~s}$ & $0 \mathrm{~s}$ \\
\hline $40 \%$ & $0 \mathrm{~s}$ & $0 \mathrm{~s}$ & $0 \mathrm{~s}$ & $0 \mathrm{~s}$ & $0 \mathrm{~s}$ & $0 \mathrm{~s}$ \\
\hline $60 \%$ & $0 \mathrm{c}$ & $0 \mathrm{~s}$ & $0 \mathrm{c}$ & $0 \mathrm{c}$ & $0 \mathrm{~s}$ & $0 \mathrm{c}$ \\
\hline K & 100 & 100 & 100 & 100 & 100 & 100 \\
\hline S5A & A. alternata & P. funiculosum & A. niger & T. viride & C. herbarum & Ch. globosum \\
\hline $10 \%$ & 84 & 48 & 20 & 20 & 60 & 60 \\
\hline $20 \%$ & 80 & 14 & $0 \mathrm{~s}$ & $0 \mathrm{~s}$ & 40 & 10 \\
\hline $40 \%$ & 80 & 10 & $0 \mathrm{~s}$ & $0 \mathrm{~s}$ & 40 & $0 \mathrm{~s}$ \\
\hline $60 \%$ & 56 & 0 & $0 \mathrm{~s}$ & $0 \mathrm{~s}$ & 40 & $0 \mathrm{~s}$ \\
\hline $\mathrm{K}$ & 100 & 100 & 100 & 100 & 100 & 100 \\
\hline S5N & A. alternata & P. funiculosum & A. niger & T. viride & C. herbarum & Ch. globosum \\
\hline $10 \%$ & 80 & 52 & 70 & $0 \mathrm{~s}$ & 72 & 80 \\
\hline $20 \%$ & 80 & 20 & $0 \mathrm{~s}$ & $0 \mathrm{~s}$ & 40 & 40 \\
\hline $40 \%$ & 80 & 10 & $0 \mathrm{~s}$ & $0 \mathrm{~s}$ & 40 & $0 \mathrm{~s}$ \\
\hline $60 \%$ & 50 & 10 & $0 \mathrm{~s}$ & $0 \mathrm{~s}$ & 40 & $0 \mathrm{~s}$ \\
\hline $\mathrm{K}$ & 100 & 100 & 100 & 100 & 100 & 100 \\
\hline BiostatA & A. alternata & P. funiculosum & A. niger & T. viride & C. herbarum & Ch. globosum \\
\hline $0.5 \%$ & 100 & 100 & 100 & 100 & 100 & 60 \\
\hline $1 \%$ & 10 & 70 & 70 & 40 & 50 & 30 \\
\hline $\mathrm{K}$ & 100 & 100 & 100 & 100 & 100 & 100 \\
\hline BiostatN & A. alternata & P. funiculosum & A. niger & T. viride & C. herbarum & Ch. globosum \\
\hline $0.5 \%$ & 100 & 100 & 100 & 100 & 100 & 60 \\
\hline $1 \%$ & 30 & 70 & 70 & 40 & 50 & 30 \\
\hline K & 100 & 100 & 100 & 100 & 100 & 100 \\
\hline
\end{tabular}

Notes: c-fungicidal effect, s-fungistatic effect, A-alkaline $\mathrm{pH}$ of growth media, $\mathrm{N}$-neutral $\mathrm{pH}$ of growth media, $\mathrm{K}$-control growth media.

Growth of Penicillium funiculosum was significantly inhibited by all tested slags; besides analogically, as with the previous model microorganisms, the highest growth inhibition was detected in the presence of slag S4. Based on a comparison of the growth intensity of P. funiculosum in the presence of the tested slags, the sequence of inhibiting efficiency of individual slags decreased in the order: $\mathrm{S} 4>\mathrm{S} 3>\mathrm{S} 1 \mathrm{a}>\mathrm{S} 1 \mathrm{~b}>\mathrm{S} 5>\mathrm{S} 2$. Total growth inhibition of Aspergillus niger was detected in the presence of all tested slags, with the exception of slag S5, at a concentration of $10 \%$ in growth media at both neutral and alkaline $\mathrm{pH}$. Slag $\mathrm{S} 4$ possessed a fungicidal (lethal) effect on the fungal spores of A. niger at a concentration of $60 \%$ in growth media at neutral $\mathrm{pH}$. The sequence of inhibiting efficiency of individual slags on $A$. niger growth decreased in the order: $\mathrm{S} 4>\mathrm{S} 1 \mathrm{a}=\mathrm{S} 1 \mathrm{~b}=\mathrm{S} 2=\mathrm{S} 3>\mathrm{S} 5$. No Trichoderma viride growth was detected in the presence of all tested slags, with exception of slag S5, at a concentration of $10 \%$ in growth media at alkaline $\mathrm{pH}$. Slag $\mathrm{S} 4$ had a fungicidal (lethal) effect on fungal spores of T. viride at a concentration of $60 \%$ in growth media at alkaline as well as neutral $\mathrm{pH}$. The inhibiting efficiency of the individual slags on T. viride growth decreased in the order: $\mathrm{S} 4>\mathrm{S} 1 \mathrm{a}=$ $\mathrm{S} 1 \mathrm{~b}=\mathrm{S} 2=\mathrm{S} 3>\mathrm{S} 5$.

Slag S4 possessed the highest inhibiting efficiency on Cladosporium herbarum growth. Complete growth inhibition of the fungal biodeteriogen $\mathrm{C}$. herbarum was detected at all tested $\mathrm{S} 4$ concentrations, with the exception of a concentration of $10 \%$ in growth media at alkaline $\mathrm{pH}$, when the growth inhibition of $C$. herbarum was on the level of $40 \%$. No growth was detected in the presence of S1b and S3 slags at a concentration of $60 \%$ in growth media at either neutral or alkaline $\mathrm{pH}$ and in the presence 
of S1a at neutral $\mathrm{pH}$ in growth media. Partial growth inhibition of $C$. herbarum was observed in the tested slags S2 and S5. The comparison study of the growth intensity of C. herbarum in the presence of the tested slags showed that the inhibiting efficiency of the individual slags decreased in the order: S4 > $\mathrm{S} 3>\mathrm{S} 1 \mathrm{~b}>\mathrm{S} 1 \mathrm{a}>\mathrm{S} 5>\mathrm{S} 2$. Total growth inhibition of Chaetomium globosum was detected in the presence of slag S4, even from the lowest concentration of $10 \%$ in growth media. Similarly, complete growth inhibition was observed in the presence of slags S1a and S5, however, only at high concentration values of 40 and $60 \%$ in growth media, and as in the presence of slag S3 even at the highest concentration of $60 \%$ in growth media. Partial growth inhibition of Ch. globosum was observed in the presence of slags $\mathrm{S} 1 \mathrm{~b}$ and S2. A comparison of growth intensity of Ch. globosum in the presence of the tested slags showed a decreasing inhibition efficiency of individual slags in this order: $\mathrm{S} 4>\mathrm{S} 1 \mathrm{a}=\mathrm{S} 5>\mathrm{S} 3>\mathrm{S} 1 \mathrm{~b}>\mathrm{S} 2$.

From the above-mentioned results, it is evident that the model filamentous fungi used were sensitive to the presence of slag samples in various ways. As is apparent from the results of inhibition, all slags inhibited the growth of filamentous fungi by $40-100 \%$ at a concentration of $60 \%$ slag. The most sensitive to the presence of all slags were $A$. niger and T. viride. Their growth was completely inhibited when $20-60 \%$ concentrations of all slag samples at neutral and alkaline $\mathrm{pH}$ were used. The growth of these two fungi species was stopped, thus causing a fungistatic effect. A 60\% concentration of slag S4 led to the inhibition of T. viride growth with fungicide effect (killed fungal spores). Slag S4 had the most inhibiting activity for all fungi. It completely inhibited growth of almost all model filamentous fungi in concentrations from $20-60 \%$ at alkaline $\mathrm{pH}$, with mostly a fungistatic effect. Only T. viride growth was inhibited totally with a fungicide effect at alkaline $\mathrm{pH}$ of growth media at a slag $\mathrm{S} 4$ concentration of $60 \%$. At neutral $\mathrm{pH}$ of growth media, the growth of model filamentous fungi was inhibited completely at concentrations from $40-60 \%$ of slag S4 and at slag S4 concentration of $60 \%$ with fungicide effect on A. alternata, A. niger, T. viride and Ch. globosum.

A lower inhibiting effect on filamentous fungi growth was observed in the case of slags S1a, S1b and S3, but they inhibited the growth of all tested filamentous fungi from $40-100 \%$ at a concentration of $40 \%$. The lowest impact on the growth of model filamentous fungi was observed in the presence of slags S2 and S5 in growth media, which affected only the growth of the most sensitive fungi, A. niger and $T$. viride. The most resistant was A. alternata. Its growth was most intensely inhibited by slag S4, with total inhibition observed at $40-60 \%$ of slag, with mostly a fungistatic effect. Biostat, at a concentration of $0.5 \%$ in growth media, did not affect the growth of model filamentous fungi, with exception Ch. globosum, the growth of which was inhibited by $40 \%$. Biostat at a concentration of $1.0 \%$ in growth media inhibited the growth of filamentous fungi by $30 \%$ to $70 \%$. Based on the test results, it can be stated that Biostat is characterized mainly by antibacterial and anti-yeast efficiency, and affects the growth of model filamentous fungi only to a minimum extent. Regarding the fact that model filamentous fungi were selectively sensitive to the presence of the tested slags, it is possible to determine only an approximate order of inhibition efficiency of the slags to filamentous micromycetes: $\mathrm{S} 4>\mathrm{S} 3=\mathrm{S} 1 \mathrm{a}=\mathrm{S} 1 \mathrm{~b}>\mathrm{S} 5>\mathrm{S} 2$. The $\mathrm{pH}$ values of the growth media did not significantly influence the intensity of inhibition of the model microorganisms' growth. A view of the testing arrangement in Petri dishes regarding the inhibition of Penicillium funiculosum growth in the presence of slag S1a in alkaline $\mathrm{pH}(\mathrm{A})$ of growth media is shown in Figure 1C.

\section{Discussion}

The results gained by testing the antimicrobial efficiency of individual slag samples on selected representatives of biodeteriogenic microflora can be summarized as follows: the tested slag samples are characterized by selective toxicity on the model bacteria, yeasts, and microscopic filamentous fungi; calcareous ladle slag (S4) possesses the highest antimicrobial efficiency; slag S4 best inhibits the growth of bacteria, yeasts, and microscopic filamentous fungi of all tested slags; total growth inhibition of Trichoderma viride and Aspergillus niger was detected in the presence of all tested slags at a concentration of $10 \%$ in growth media, except for copper slag (S5); the calcareous ladle slag (S4) and granulated blast-furnace slag with a specific surface area of $340 \mathrm{~m}^{2} / \mathrm{kg}$ (S1a) possessed fungicidal (lethal) effect 
on spores of some filamentous fungi at a concentration of $60 \%$ in growth media; copper slag (S5) is characterized by the lowest antibacterial and anti-yeast efficiency, despite having the highest $\mathrm{Cu}, \mathrm{Cr}$, $\mathrm{Co}, \mathrm{Ni}, \mathrm{As}, \mathrm{Zn}, \mathrm{Pb}$, and $\mathrm{Hg}$ contents from all tested slags; air cooled blast-furnace slag (S2) and copper slag (S5) have the lowest antifungal efficiency. Biostat at concentrations of $0.5 \%$ and $1 \%$ in growth media inhibited the growth of bacteria, at a concentration of $1 \%$ inhibited the growth of yeasts, at a concentration of $0.5 \%$ did not affect the growth of filamentous fungi at all, and at a concentration of $1 \%$ inhibited the growth of filamentous fungi only to a minimum extent. However, the mechanism and biochemical processes of the antimicrobial efficiency of the metallurgical slags should be the subject of further study.

Generally, calcareous ladle slag (S4) possesses the highest antimicrobial efficiency and inhibits the growth of bacteria, yeasts and microscopic filamentous fungi most of all the tested slags. Slag S4 is characterized as having the highest $\mathrm{CaO}$ content of $58.97 \mathrm{wt} \%$ and the highest $\mathrm{CaO}_{\text {free }}$ content (3.30 wt \%) as well as the highest $\mathrm{pH}$ (12.93), in comparison with the other tested slags. Antimicrobial activity of metallurgical slags, with their very high $\mathrm{CaO}$ and $\mathrm{CaO}_{\text {free }}$ contents, as well as their very high $\mathrm{pH}$ of water leachate, as in the case of slag $\mathrm{S4}$, could be roughly similar to the antimicrobial efficiency of lime $[12,13]$. However, calcareous metallurgical slags cause an increase in the $\mathrm{pH}$ values of water leachates up to the range of about 11.5-12.9 due to their high $\mathrm{CaO}$ content, e.g., similarly in the case of granulated blast furnace slag, cements and cement and granulated blast furnace slag mixtures, and concretes in the wet state, when they hydrate $[1,2,6]$, which affects the viability of microorganisms. This effect is similar to the effect of lime during sanitisation (hygienisation). Disinfection by lime at a wastewater treatment plant reduces the number of microorganisms extensively when operated at $\mathrm{pH} 11.2$ [12]. Lime enables the destruction of all pathogens due to the $\mathrm{pH}$ effect; it provides alkaline hydrolysis, combined with the temperature increase that quicklime hydration brings (thermolysis) [13]. Of course, the thermolysis effect can be excluded in the case of metallurgical slags in comparison with lime, but alkaline hydrolysis can be considered as an antimicrobial potential of metallurgical slags. Alkaline hydrolysis $\left(\mathrm{OH}^{-}\right)$results in the destruction of protein-based cellular walls and of enzymes, the destruction of proteins at polypeptide bonds to amino acids and oligopeptides, the destruction of nucleic acids (RNA), the destruction of carbohydrate cell constituents and lipids and the denaturing of enzymes [13]. In order to grow, microorganisms need certain optimal environmental conditions (humidity, nutrients, osmotic pressure, temperature, light, $\mathrm{pH}$ of surroundings, etc.), which guarantee their optimal growth. Microorganisms grow at $\mathrm{pH}$ values from 2.5 to 9 , and the optimal value of $\mathrm{pH}$ for growth of various microorganisms lies in the interval from 5 to 7.5 , although exceptions do exist. In general, most microorganisms grow in a neutral or slightly alkaline environment $(\mathrm{pH}=7$ and slightly over $\mathrm{pH}>7$ ), whereas the majority of filamentous fungi (moulds) requires an acidic environment, i.e., a $\mathrm{pH}$ lower than 7. As long as the antimicrobial substances in a wet environment increase the $\mathrm{pH}$ value over $\mathrm{pH}>7$, the growth of fungi decreases and at the $\mathrm{pH}>9$ also the growth of bacteria. It is possible to achieve biocide (deadly) effect on microorganisms by a $\mathrm{pH}$ increase [1,2].

\section{Conclusions}

Based on the obtained results, the antibacterial efficiency of individual slag samples decreased in the order: $\mathrm{S} 4>\mathrm{S} 3>\mathrm{S} 2>\mathrm{S} 1 \mathrm{a}=\mathrm{S} 1 \mathrm{~b}>\mathrm{S} 5$. The decrease in anti-yeast efficiency of the individual slag samples was in the order: $\mathrm{S} 4>\mathrm{S} 1 \mathrm{a}=\mathrm{S} 1 \mathrm{~b}=\mathrm{S} 3>\mathrm{S} 2>\mathrm{S} 5$. Model filamentous fungi were selectively sensitive to the presence of tested slags, but it is only possible to determine the approximate order of inhibition efficiency of slags to filamentous micromycetes: $\mathrm{S} 4>\mathrm{S} 3=\mathrm{S} 1 \mathrm{a}=\mathrm{S} 1 \mathrm{~b}>\mathrm{S} 5>\mathrm{S} 2$. Calcareous ladle slag (S4) has the highest antimicrobial efficiency, while granulated blast-furnace slag (S1a, S1b) and demetallized steel slag (S3) have medium activity. Air cooled blast-furnace slag (S2) has still lower activity and copper slag (S5) has the lowest activity. According to these results, metallurgical slags possess great potential for use as active antimicrobial agents for building materials, as well as antimicrobial components against the biocorrosion and biodeterioration of building materials and products. 
Author Contributions: As the primary authors, Július Strigáč, Nadežda Števulová, and Jozef Mikušinec prepared the overall research concept and initiated the study. Daniela Hudecová and L'udovít Varečka performed the antimicrobial efficiency tests, analysed the data, and interpreted it, contributed to the manuscript writing, and prepared the final draft of the manuscript. Július Strigáč, Nadežda Števulová, and Jozef Mikušinec completed the initial manuscript, critically revised the content of the paper, and contributed to the editing and structuring the paper and advising on the data analysis.

Conflicts of Interest: The authors declare no conflict of interest.

\section{References}

1. Cwalina, B. Biodeterioration of concrete. Archit. Civ. Eng. Environ. 2008, 4, 133-140.

2. George, R.P.; Vishwakarma, V.; Samal, S.S.; Mudali, U.K. Current understanding and future approaches for controlling microbially influenced concrete corrosion: A review. Concr. Res. Lett. 2012, 3, 491-506.

3. House, M.W.; Weiss, W.J. Review of microbially induced corrosion and comments on needs related to testing procedures. In Proceedings of the 4th International Conference on the Durability of Concrete Structures, West Lafayette, IN, USA, 24-26 July 2014; Olek, J., Weiss, J., Eds.; pp. 94-103.

4. Strigáč, J.; Martauz, P.; Eštoková, A.; Števulová, N.; Luptáková, A. Bio-corrosion resistance of concretes containing antimicrobial ground granulated blastfurnace slag BIOLANOVA and novel hybrid H-CEMENT. Solid State Phenom. 2016, 244, 57-64. [CrossRef]

5. Giannantonio, D.J.; Kurth, J.C.; Kurtis, K.E.; Sobecky, P.A. Effects of concrete properties and nutrients on fungal colonization and fouling. Int. Biodeterior. Biodegrad. 2009, 63, 252-259. [CrossRef]

6. Strigáč, J.; Martauz, P. Fungistatic properties of granulated blastfurnace slag and related slag-containing cements. Ceramics-Silikáty 2016, 60, 19-26. [CrossRef]

7. Euroslag Technical Leaflet No. 1: Granulated Blastfurnace Slag. Duisburg, Germany, 2003; pp. 1-4. Available online: http://www.euroslag.com/fileadmin/_media/images/Research/FACT_SHEETS/LeafletGBS.pdf (accessed on 1 January 2003).

8. Sofilić, T.; Rastovčan-Mioč, A.; Ćosić, M.; Merle, V.; Mioč, B.; Sofilić, U. Steel Slag Application in Croatian Asphalt Mixture Production. In Proceedings of the International Scientific Conference on Management of Technology—Step to Sustainable Production, MOTSP 2010, Rovinj, Croatia, 2-4 June 2010; pp. 1-6. Available online: https: / bib.irb.hr/datoteka/476347.185-sofili-rastovcan-mioc.pdf (accessed on 2 June 2010).

9. Yildirim, I.Z.; Prezzi, M. Chemical, Mineralogical, and Morphological Properties of Steel Slag. Adv. Civ. Eng. 2011, 2011. [CrossRef]

10. Lewis, D.W. Properties and Uses of Iron and Steel Slags; Document MF 182-6; National Slag Association: Pleasant Grove, UT, USA, 1992; pp. 1-11. Available online: http:/ / www.nationalslag.org/sites/nationalslag/files / documents/nsa_182-6_properties_and_uses_slag.pdf (accessed on 1 April 1992).

11. Serjun, V.Z.; Mirtič, B.; Mladenovič, A. Evaluation of ladle slag as a potential material for building and civil engineering. Mater. Technol. 2013, 47, 543-550, Article UDK 669.186.002.8.

12. Grabow, W.O.K.; Middendorf, I.G.; Basson, N.C. Role of lime treatment in the removal of bacteria, enteric viruses and coliphages in a wastewater reclamation plant. Appl. Environ. Microbiol. 1978, 35, 663-669. [PubMed]

13. Remy, M. Scientific evidence on the effectiveness of lime. In Proceedings of the Conference Animal Health and Welfare: A Sustainable Solution from Industry, Brussels, Belgium, 18 February 2009; European Lime Association, Ed.; EuLA c/o IMA-Europe. pp. 11-21. Available online: http:/ /www.eula.eu/; http:/ / www. ima-europe.eu/; http:/ / www.carmeuse.com/; http:/ / www.codecal.com/page.asp?id=164\&langue=EN; http: / / www.eula.eu/documents/eula-practical-guidelines-disinfection-lime (accessed on 18 February 2009).

(C) 2018 by the authors. Licensee MDPI, Basel, Switzerland. This article is an open access article distributed under the terms and conditions of the Creative Commons Attribution (CC BY) license (http:/ / creativecommons.org/licenses/by/4.0/). 